University of Nebraska - Lincoln

DigitalCommons@University of Nebraska - Lincoln

Faculty Papers and Publications in Animal

Science

Animal Science Department

March 1974

\title{
RELATIONSHIP OF VARIOUS MEASURES OF PERFORMANCE WITH OVULATION RATE AND NUMBER OF EMBRYOS 30 DAYS AFTER BREEDING IN GILTS
}

L. D. Young

Oklahoma Agricultural Experiment Station, Stillwater and USDA, El Reno

I. T. Omtvelt

Oklahoma Agricultural Experiment Station, Stillwater and USDA, El Reno, iomtvedt1@unl.edu

R. K. Johnson

University of Nebraska-Lincoln, rjohnson5@unl.edu

Follow this and additional works at: https://digitalcommons.unl.edu/animalscifacpub

Part of the Animal Sciences Commons

Young, L. D.; Omtvelt, I. T.; and Johnson, R. K., "RELATIONSHIP OF VARIOUS MEASURES OF PERFORMANCE WITH OVULATION RATE AND NUMBER OF EMBRYOS 30 DAYS AFTER BREEDING IN GILTS" (1974). Faculty Papers and Publications in Animal Science. 9.

https://digitalcommons.unl.edu/animalscifacpub/9

This Article is brought to you for free and open access by the Animal Science Department at DigitalCommons@University of Nebraska - Lincoln. It has been accepted for inclusion in Faculty Papers and Publications in Animal Science by an authorized administrator of DigitalCommons@University of Nebraska - Lincoln. 


\title{
RELATIONSHIP OF VARIOUS MEASURES OF PERFORMANCE WITH OVULATION RATE AND NUMBER OF EMBRYOS 30 DAYS AFTER BREEDING IN GILTS ${ }^{1}$
}

\author{
L. D. Young, I. T. Omtvedt ${ }^{2}$ and R. K. Johnson
}

Oklahoma Agricultural Experiment Station, Stillwater and U. S. Department of Agriculture, El Reno 74074

\begin{abstract}
Summary
This study involved the records of 241 purebred Duroc, Hampshire and Yorkshire gilts and 103 two-breed cross gilts resulting from all possible crosses among the purebreds. In purebred gilts, the number of corpora lutea was correlated $(\mathrm{P}<.05)$ with average daily gain $(\mathrm{r}=$ $0.15)$, age at $100 \mathrm{~kg}(\mathrm{r}=-.17)$, breeding weight $(\mathrm{r}=0.23)$ and days from $100 \mathrm{~kg}$ to breeding $(\mathrm{r}=$ 0.20 ). In two-breed cross gilts, the number of corpora lutea was correlated $(\mathrm{P}<.05)$ with birth weight $(\mathrm{r}=0.25)$, weaning weight $(\mathrm{r}=$ $0.28)$, average daily gain $(\mathrm{r}=0.20)$, age at 100 $\mathrm{kg}(\mathrm{r}=-.20)$ and breeding weight $(\mathrm{r}=0.46)$.

The size of the litter the gilt was born or weaned in, her birth weight, average daily gain, age at $100 \mathrm{~kg}$, and backfat probe were not significantly correlated with the number of embryos she had 30-days postbreeding regardless of the type of breeding of the embryo. The correlation between the gilt's weaning weight and number of embryos was significant $(P<.05)$ for gilts with three-breed cross embryos but not for gilts with purebred or two-breed cross embryos ( $\mathrm{r}=0.35,0.02$ and 0.11 , respectively). Breeding age and days from $100 \mathrm{~kg}$ to breeding were correlated $(\mathrm{P}<.05)$ with the number of embryos for gilts with two-breed cross embryos ( $\mathrm{r}=0.17$ and 0.15 , respectively) but these correlations were not

\footnotetext{
' Journal article 2738 of the Agricultural Experiment Station, Oklahoma State University, Stillwater. Research conducted by the Department of Animal Sciences and Industry (Project 1444) in cooperation with Animal Science Research Division, Agricultural Research Service, U.S.D.A.

${ }^{2}$ Present address: Alabama Agricultural Experiment Station, Auburn University, Auburn 36830.
}

significant for gilts with purebred embryos ( $\mathrm{r}=$ -.13 and -.05 , respectively) or for gilts with three-breed cross embryos ( $\mathrm{r}=-.05$ and 0.14 , respectively). The correlation between breeding weight and number of embryos was significant for gilts with two-breed cross and three-breed cross embryos ( $\mathrm{r}=0.15$ and 0.41 , respectively) but not for gilts with purebred embryos $(\mathrm{r}=$ -.03 ). Ovulation rate accounted for $13.7,5.8$ and $23.0 \%$ of the variation in the number of purebred, two-breed cross and three-breed cross embryos, respectively $(P<.05)$.

\section{Introduction}

The number of pigs raised per sow is of great economic importance to the swine producer. Previous research has shown that the heritability of litter size is low with most estimates falling in the range of 0 to $15 \%$. In fact, there is some evidence to suggest that gilts selected from larger than average litters have smaller litters than gilts selected from smaller than average litters (Revelle and Robison, 1973).

Even though litter size has been shown to be affected by age, weight and breeding (Stewart, 1945; Squiers, Dickerson and Mayer, 1952; Rathnasabapathy, Lasely and Mayer, 1956; Omtvedt, Stanislaw and Whatley, 1965; Johnson and Omtvedt, 1973b), there is still great variability in the size of litters produced by females that are similar in these characteristics. If a portion of the variability in ovulation rate and litter size can be accounted for in terms of measures of performance, then selecting more productive replacement gilts would be more effective.

This study was initiated to evaluate 1) the degree of relationship between various measures of performance and ovulation rate for purebred 
TABLE 1. DISTRIBUTION OF GILTS BY BREED AND BREEDING SEASON ${ }^{\mathrm{a}}$

\begin{tabular}{lrrrrr}
\hline \hline $\begin{array}{l}\text { Breed } \\
\text { of gilt }\end{array}$ & \multicolumn{1}{c}{ F1970 } & S1971 & F1971 & S1972 & F1972 \\
\hline $\begin{array}{l}\text { Duroc } \\
\text { Hampshire }\end{array}$ & 14 & 29 & 14 & 16 & 21 \\
$\begin{array}{l}\text { Yorkshire } \\
\text { D-H }\end{array}$ & 15 & 8 & 9 & 21 & 18 \\
$\begin{array}{l}\text { crosses b } \\
\text { D-Y }\end{array}$ & - & - & 13 & 20 & - \\
$\begin{array}{c}\text { crosses } \\
\text { H-Y } \\
\text { crosses }\end{array}$ & - & - & 15 & 22 & - \\
\hline
\end{tabular}

aD = Duroc; $\mathbf{H}=$ Hampshire; $Y=$ Yorkshire $; \mathbf{F}=$ Fall; $\mathbf{S}=$ Spring.

IInvolved reciprocal crosses.

Duroc, Hampshire and Yorkshire gilts compared to two-breed cross gilts and 2) to compare the degree of relationship between various measures of performance and number of embryos for purebred gilts with purebred embryos, purebred gilts with two-breed cross embryos and two-breed cross gilts with three-breed cross embryos.

\section{Materials and Methods}

The data were obtained from the first three replications of phase $I$ and the first two replications of phase II of the Oklahoma swine breeding project being conducted at the Fort Reno Experiment Station. The formation and maintenance of the seedstock herds that provided the purebred boars and gilts used in this study has previously been described by Johnson, Omtvedt and Walters (1973a).

This study included the records on 241 purebred Duroc, Hampshire and Yorkshire gilts and 103 two-breed cross gilts involving all possible crosses among the three pure breeds. The data came from five breeding seasons starting with the fall of 1970 through the fall of 1972. The fall breeding season started on December 1 and the spring breeding season started on June 1 and each season was long enough to allow problem breeders to have at least three complete estrous cycles. The distribution of gilts by breed group and breeding season are reported in table 1 . The mating system is summarized in table 2 and has previously been described by Johnson et al. (1973b). In three of the five seasons purebred gilts were bred to carry purebred or two-breed cross embryos. In the remaining two seasons, purebred gilts were bred to carry two-breed cross embryos and two-breed cross gilts were bred to carry three-breed cross embryos.

All gilts in this study were born in confinement, given creep feed at 21 days of age and were weaned at 42 days of age. Two weeks after weaning, the gilts and barrows were moved to a confinement finishing facility and were allotted by breed group into groups of 16 pigs per pen. They were given 1 week to adjust to their new surroundings before beginning test weights were taken. All gilts were fed a $16 \%$ crude protein ration until they reached 100 kilograms. Gilts were weighed off test on a weekly basis as they reached $100 \mathrm{~kg}$, probed for

TABLE 2. BASIC MATING SYSTEM FOR EACH REPLICATION ${ }^{a}$

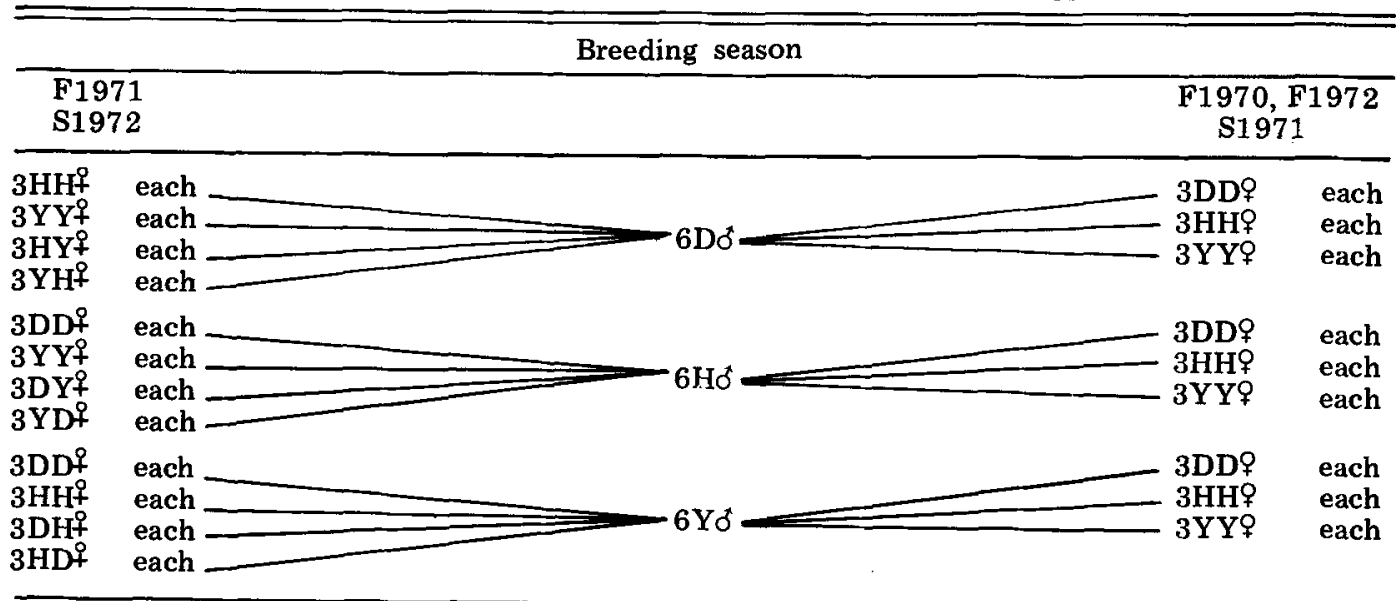

$a_{D}=$ Duroc, $H=$ Hampshire, $Y=$ Yorkshire; the first letter is the breed of sire and the second is breed of dam. 
backfat thickness and moved outside to dirt lots where they were individually limit fed. In the summer they received $1.82 \mathrm{~kg}$ per head per day and in the winter they received $2.04 \mathrm{~kg}$ per head per day of a $15 \%$ crude protein ration. Two weeks prior to the start of the breeding season, they were flushed by increasing their feed by $0.68 \mathrm{~kg}$ per head per day and after breeding the feed was reduced to the preflushing level.

The average age at breeding was 271 days and ranged from 198 days to 343 days of age. During the breeding season, the gilts were checked for estrus daily by use of a teaser boar and were hand mated. Whenever possible, repeat matings were made between 12 and 24 $h r$. after the first service. If a gilt exhibited heat at the next cycle, she was rebred, otherwise she was assumed pregnant. One gilt from each boar-mating type was randomly selected to be slaughtered and they were sacrificed on a weekly basis approximately 30 days postbreeding. The reproductive tracts were collected and dissected and all embryos were removed and counted. Ovulation rate was measured by the number of corpora lutea on the ovaries.

The initial analysis consisted of correlating the various measures of performance with the number of corpora lutea and number of embryos within breed and season. The correla. tions between the same traits in different seasons were not significantly different. The correlations of the various traits with ovulation rate were pooled for all purebreds from the within breed and season analysis and the correlations of the various traits with ovulation rate were pooled for all crossbreds from the within breed and season analysis. The correlations for purebreds and crossbreds were kept separate to evaluate the effect of crossbreeding on the relationship between the various traits and ovulation rate.

In evaluating the degree of relationship of the various traits with the number of embryos, three classifications were established based on the type of breeding of the embryo. They were purebred gilts with purebred embryos, purebred gilts with two-breed cross embryos and two-breed cross gilts with three breed cross embryos. These classes were established to evaluate the effect of the mating type and resulting types and degrees of heterosis on the relationship between the number of embryos and the various performance measures. The correlations for each group were the result of pooling from the within breed and season analysis for the types of gilts of which the group was composed.

\section{Results and Discussion}

Means and Standard Deviations. The means and standard deviations are reported in table 3 by the type of breeding of the embryo the gilt carried. There were few large differences between group means. One of the largest differences occurred in age at breeding with crossbred gilts averaging 20 days younger than the purebreds. Other researchers have shown that crossbred gilts reach puberty about 14.5 days earlier than purebreds (Clark et al., 1970). If this is true, then the purebred and crossbred gilts in this study should be in about the same estrous cycle. Since the crossbred gilts were younger at breeding and slightly older at 100 $\mathrm{kg}$, they also had fewer days from $100 \mathrm{~kg}$ to breeding. This latter measure was introduced to see if this period of physiological maturation was more important in predicting fertility than was actual age at breeding.

Factors associated with Ovulation Rate in Purebred and Two-Breed Cross Gilts. The pooled correlations among all traits are reported in table 4 for two-breed cross gilts and in table 5 for purebred gilts. Neither the size of the litter a gilt was born in or weaned in was significantly correlated with her ovulation rate in purebred gilts $(r=0.03$ and 0.03 , respectively) or two-breed cross gilts ( $r=-.06$ and -.01 , respectively). This indicates that replacement gilts from large litters should not be expected to have a higher ovulation rate than replacement gilts from small litters.

Ovulation rate was not significantly correlated with birth weight or weaning weight in purebred gilts ( $r=0.03$ and 0.11 , respectively) but was significantly correlated $(P<.05)$ with birth weight and weaning weight in two-breed cross gilts ( $\mathrm{r}=0.25$ and 0.28 , respectively). The correlations for two-breed cross gilts were not significantly different from their respective correlations for purebred gilts. Rathnasabapathy et al. (1956) reported the correlations of 0.12 and 0.33 for ovulation rate with birth and weaning weights, respectively.

The correlations of ovulation rate with average daily gain and age at $100 \mathrm{~kg}$ were significant $(P<.05)$ and similar for purebred gilts $(r=0.15$ and -.17 , respectively) and two-breed cross gilts $(r=0.20$ and -.20 , respectively) with gilts that gained faster and thus being younger at $100 \mathrm{~kg}$ having a higher ovulation rate. This is similar to the correlation of 0.20 reported by Squiers et al. (1952) between growth rate and ovulation rate when age at breeding was held constant and similar to the correlation of 0.22 obtained by Rath- 
TABLE 3. MEANS AND STANDARD DEVIATIONS FOR ALL TRAITS STUDIED BY GROUP OF GILT

\begin{tabular}{|c|c|c|c|c|c|c|}
\hline \multirow[t]{2}{*}{ Item } & \multicolumn{2}{|c|}{$\begin{array}{l}\text { Purebred gilts } \\
\text { with purebred } \\
\text { embryos }\end{array}$} & \multicolumn{2}{|c|}{$\begin{array}{l}\text { Purebred gilts } \\
\text { with 2-breed } \\
\text { cross embryos }\end{array}$} & \multicolumn{2}{|c|}{$\begin{array}{l}\text { 2-breed gilts } \\
\text { with 3-breed } \\
\text { cross embryos }\end{array}$} \\
\hline & Means & SD & Means & $\underline{\text { SD }}$ & Means & $\underline{\text { SD }}$ \\
\hline Number of gilts & 56 & & 185 & & 103 & \\
\hline Size of litter born in & 10.57 & 2.40 & 10.69 & 2.62 & 10.33 & 2.25 \\
\hline Size of litter weaned in & 7.59 & 2.12 & 7.72 & 2.22 & 7.77 & 1.92 \\
\hline Birth weight, $\mathbf{k g}$ & 1.35 & 0.28 & 1.34 & 0.25 & 1.23 & 0.24 \\
\hline Weaning weight, $\mathbf{k g}$ & 10.71 & 2.05 & 11.03 & 2.39 & 10.79 & 2.25 \\
\hline Avg daily gain, $\mathrm{kg}$ & 0.62 & 0.06 & 0.61 & 0.05 & 0.62 & 0.06 \\
\hline Age at $100 \mathrm{~kg}$ & 177.27 & 12.85 & 181.22 & 14.32 & 184.59 & 12.85 \\
\hline Backfat thickness, cm & 2.87 & 0.30 & 2.97 & 0.38 & 3.15 & 0.38 \\
\hline Breeding age, days & 279.93 & 16.49 & 275.94 & 21.02 & 256.38 & 22.01 \\
\hline Breeding weight, $\mathrm{kg}$ & 115.37 & 10.84 & 119.50 & 11.90 & 119.17 & 12.04 \\
\hline Slaughter weight, $\mathrm{kg}$ & 121.64 & 11.36 & 127.80 & 12.18 & 131.07 & 13.52 \\
\hline Days from $100 \mathrm{~kg}$ to breeding & 102.66 & 21.29 & 94.86 & 25.81 & 71.79 & 24.97 \\
\hline Number of corpora lutea & 12.89 & 2.11 & 13.38 & 2.32 & 13.13 & 2.31 \\
\hline Number of embryos & 10.12 & 2.24 & 10.34 & 2.89 & 10.73 & 2.98 \\
\hline
\end{tabular}

nasabapathy et al. (1956). In this study an increase of $0.045 \mathrm{~kg}$ in average daily gain was associated with an increase in ovulation rate of $0.28 \pm .12$ and $0.34 \pm .19$ ova for purebred and two-breed cross gilts, respectively. A decrease of 10 days in age at $100 \mathrm{~kg}$ was associated with an increase in ovulation rate of $0.27 \pm .10$ and $0.44 \pm .09$ ova for purebred and two-breed cross gilts, respectively.

Probe backfat was not associated with ovulation rate in either type of gilt. The correlation between breeding weight and ovulation rate was 0.23 and $0.46(\mathrm{P}<.05)$ for purebred and two-breed cross gilts, respectively, and the correlations were significantly different from each other. An increase of $4.54 \mathrm{~kg}$ in breeding weight was associated with an increase in ovulation rate of $0.20 \pm .08$ and $0.40 \pm .08$ eggs for purebred and two-breed cross gilts, respectively. In the ranges studied and under this management system, the correlation between age at breeding and ovulation rate was not significant $(\mathrm{P}<.05)$ for purebred or two-breed cross gilts $(\mathrm{r}=0.12$ and -.04 , respectively). This indicates that in these gilts, weight at breeding affected ovulation rate more than age at breeding. These results are in agreement with results reported by Warnick et al. (1951), Rio (1957) and Stewart (1945). Robertson et al. (1951) found that weight at puberty and age at puberty accounted for $13.0 \%$ and $3.6 \%$ of the variation in ovulation rate at the second estrus, respectively. Rath- nasabapathy et al. (1956) found that age at breeding accounted for $10.2 \%$ of the variation in ovulation rate.

The correlation between ovulation rate and days from $100 \mathrm{~kg}$ to breeding was significant $(P<.05)$ for purebred gilts $(r=0.20)$ but not for two-breed cross gilts $(r=0.07)$ but the correlations were not significantly different from each other. An increase of 10 days in days from $100 \mathrm{~kg}$ to breeding was associated with an increase of $0.18 . \pm .06$ eggs for purebred gilts and $0.16 \pm .12$ eggs for two-breed cross gilts.

In general these data indicate that gilts that are heavier at weaning, grow faster and are heavier at breeding should have a higher ovulation rate.

Comparison of the Relationship of the Various Traits with Number of Normal Embryos for Gilts with Purebred, Two-breed Cross and Three-breed Cross Embryos. The correlations between the various traits and the number of embryos are reported in table 6 by the type of breeding of the embryo.

Although the correlations were not significantly different from zero, the correlations between the size of litter the gilt was born in and the number of embryos she had 30-days postbreeding were negative and the correlation between the size of litter she was weaned in and the number of embryos was zero or positive regardless of the breeding of the embryo. The size of litter born in was associated with $25 \%$ of the variation in the size of litter weaned in. 


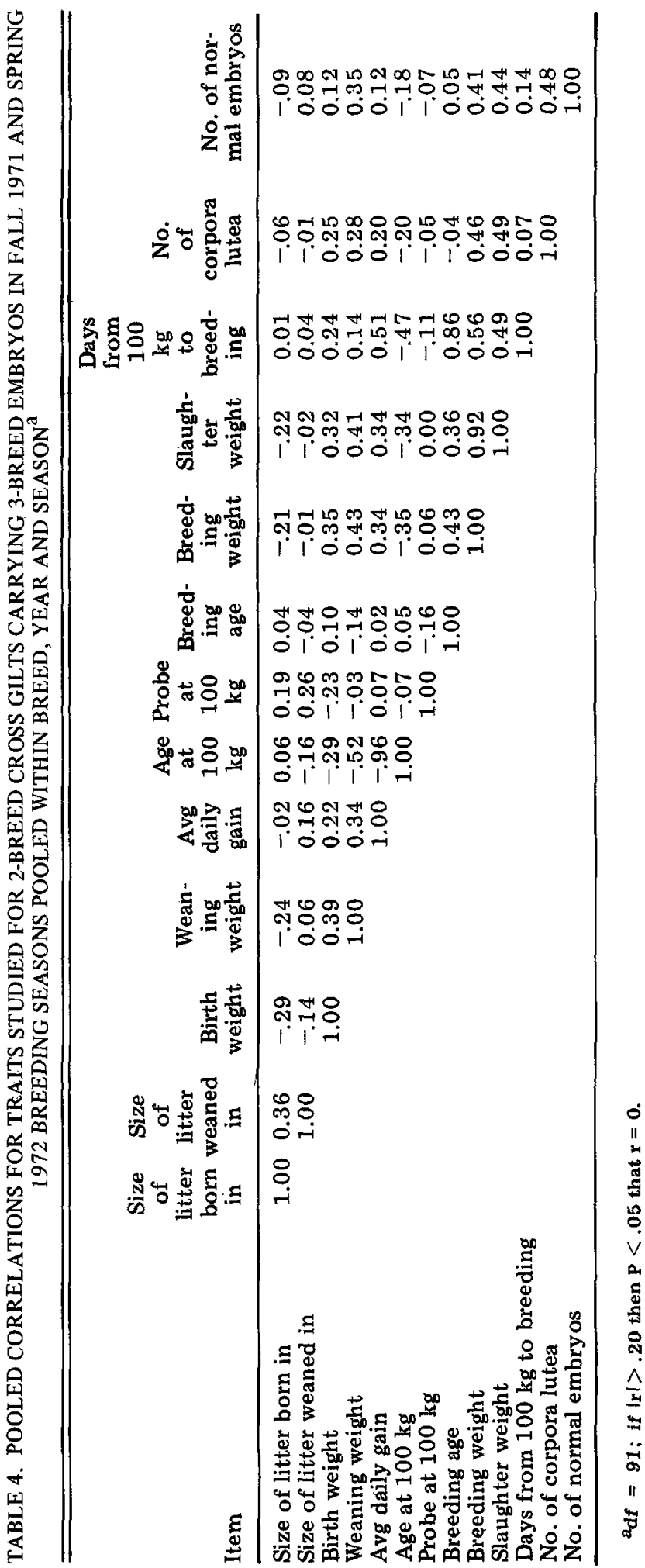




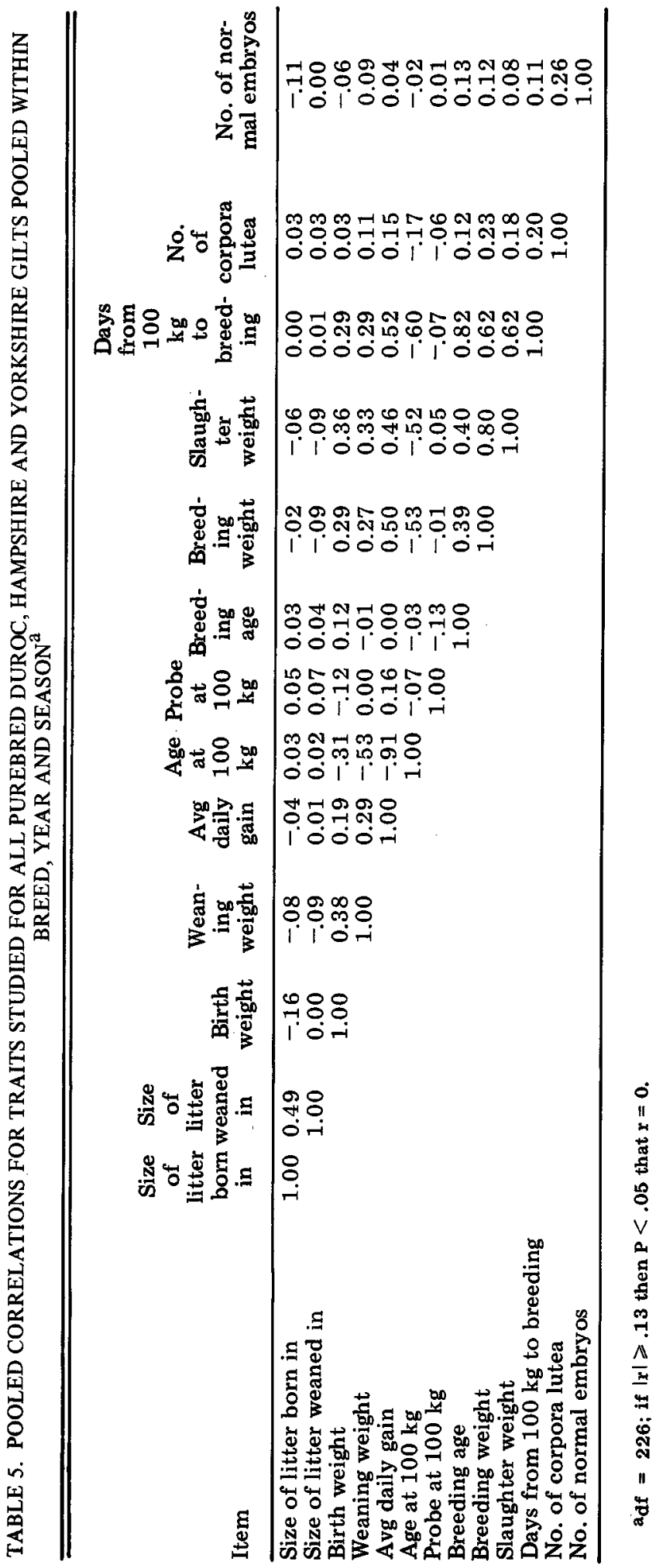


TABLE 6. POOLED CORRELATIONS BETWEEN MEASURES OF PERFORMANCE AND NUMBER OF EMBRYOS FOR GILTS WITH PUREBRED, TWO-BREED CROSS AND THREE-BREED CROSS EMBRYOS

\begin{tabular}{|c|c|c|c|}
\hline Item & $\begin{array}{l}\text { Purebred } \\
\text { embryos }\end{array}$ & $\begin{array}{c}\text { Two-breed } \\
\text { cross embry os }\end{array}$ & $\begin{array}{l}\text { Three-breed } \\
\text { cross embryos }\end{array}$ \\
\hline Size of litter born in & -.19 & -.10 & -.09 \\
\hline Size of litter weaned in & 0.05 & 0.00 & 0.08 \\
\hline Birth weight & -.04 & -.07 & 0.12 \\
\hline Weaning weight & 0.02 & 0.11 & $0.35^{\mathrm{a}}$ \\
\hline Avg daily gain & 0.16 & 0.02 & 0.12 \\
\hline Age at $100 \mathrm{~kg}$ & -.07 & -.01 & -.18 \\
\hline Probe at $100 \mathrm{~kg}$ & -.16 & 0.04 & -.07 \\
\hline Breeding age & -.13 & $0.17^{\mathrm{a}}$ & 0.05 \\
\hline Breeding weight & -.03 & $0.15^{\mathrm{a}}$ & $0.41^{\mathrm{a}}$ \\
\hline Slaughter weight & 0.02 & $0.10_{a}$ & $0.44^{\mathrm{a}}$ \\
\hline Days from 100 to $\mathrm{kg}$ breeding & -.05 & 0.15 & 0.14 \\
\hline No. of corpora lutea & $0.37^{\mathrm{a}}$ & $0.24^{\mathrm{a}}$ & $0.48^{\mathrm{a}}$ \\
\hline
\end{tabular}

${ }^{a}$ Different from zero at 0.05 level.

Prenatal or early postnatal competition in large litters may be responsible for an unfavorable effect on subsequent reproductive performance. By 42 days of age, this competition effect seems to disappear perhaps as a result of creep feed consumption. These results are in agreement with Young and Omtvedt (1973). There may be a curvilinear relationship between the size of litter a gilt came from and the size of her litter as shown by Revelle and Robison (1973). However, the overall correlation may be approximately zero as seen in this study.

Birth weight, age at $100 \mathrm{~kg}$, average daily gain and backfat probe in the ranges studied were not significantly correlated with the number of normal embryos regardless of the breeding of the embryo.

The gilt's weaning weight was correlated $(\mathrm{P}<.05)$ with the number of normal embryos for three breed cross embryos $(r=0.35)$ and this was significantly larger $(P<.05)$ than the correlations for purebred and two-breed cross embryos ( $\mathrm{r}=0.02$ and 0.11 , respectively). However, the partial correlations between weaning weight and the number of embryos holding ovulation rate constant were $0.26,0.09$ and 0.01 for gilts with three-breed cross, two-breed cross and purebred embryos, respectively. The differences between the partial correlations were not significant. An increase of $4.54 \mathrm{~kg}$ in weaning weight was associated with an increase of $0.08 \pm .87,0.59 \pm .42$ and $2.12 \pm$ .59 embryos for gilts with purebred, two-breed cross and three-breed cross embryos, respectively. Young and Omtvedt (1973) reported a correlation of 0.10 between the size of a gilt's first litter and her weaning weight and Rathnasabapathy et al. (1956) reported a correlation of 0.15 between a gilt's weaning weight and the number of embryos she had 55-days postbreeding.

Breeding age was correlated $(\mathrm{P}<.05)$ with the number of embryos for gilts with two-breed cross embryos $(\mathrm{r}=0.17)$ but was not significantly correlated with the number of embryos for gilts with purebred or three-breed cross embryos ( $\mathrm{r}=-.13$ and 0.05 , respectively). The correlations were significantly different for purebred and two-breed cross embryos. When ovulation rate was held constant, the partial correlation between breeding age and number of embryos became -.10, 0.13 and 0.04 for gilts with purebred, two-breed cross and three-breed cross embryos, respectively. None of the differences among partial correlations were significant. An increase of 10 days in age at breeding was associated with a change of $-.17 \pm 0.20,0.23 \pm 0.10$ and $0.07 \pm 0.14$ embryos for purebred, two-breed cross and three-breed cross embryos, respectively. Rathnasabapathy et al. (1956) and Squiers et al. (1952) reported a correlation of 0.32 and 0.33 , respectively, between age at breeding and number of embryos.

The correlation between breeding weight and number of embryos was significant $(P<$ .05 ) for gilts with two-breed and three-breed cross embryos ( $r=0.15$ and 0.41 , respectively) but was not significant for gilts with purebred embryos $(\mathrm{r}=-.03)$. The correlation for three-breed cross embryos was significantly larger than the correlation for purebred or 
two-breed cross embryos. The partial correlations between breeding weight and number of embryos holding ovulation rate constant were $-.18,0.10$ and 0.24 for purebred, two-breed cross and three-breed cross embryos, respectively. Only the difference between -.18 and 0.24 was significant. An increase of $4.54 \mathrm{~kg}$ in breeding weight was associated with a change of $-.03 \pm 0.24,0.16 \pm 0.08$ and $0.45 \pm 0.11$ embryos for purebred, two-breed cross and three-breed cross embryos, respectively.

The correlation between days from $100 \mathrm{~kg}$ to breeding and the number of embryos was significant $(\mathbf{P}<.05)$ for two-breed cross embryos $(r=0.15)$ but not for purebred or three-breed cross embryos $(r=-.05$ and 0.14 , respectively); however, the correlation for three-breed cross embryos was of comparable magnitude to the correlation for two-breed cross embryos. Slaughter weight was associated with $18 \%$ of the variation in number of three-breed cross embryos but was associated with a nonsignificant amount of variation for two-breed cross and purebred embryos.

Although no correlations were large, those gilts which were heavier at weaning, grew faster and were heavier at breeding ovulated more eggs. No measurements were consistently correlated with the number of embryos for purebred, two breed cross and three-breed cross embryos nor were any correlations large for any group.

\section{Literature Cited}

Clark, J. R., N. L. First, A. B. Chapman and L. E. Casida. 1970. Age at puberty in four genetic groups of swine. J. Anim. Sci. 31:1032 (Abstr.).

Johnson, R. K., I. T. Omtvedt and L. E. Walters. 1973a. Evaluation of purebreds and two-breed crosses in swine: Feedlot performance and carcass merit. J. Anim. Sci. 37:18.

Johnson, R. K. and I. T. Omtvedt. 1973b. Evaluation of purebreds and two-breed crosses in swine: Reproductive performance. J. Anim. Sci. 38:1279.

Omtvedt, I. T., C. M. Stanislaw and J. A. Whatley, Jr. 1965. Relationship of gestation length, age and weight at breeding and gestation gain to sow productivity at farrowing. J. Anim. Sci. 24:531-535.

Rathnasabapathy, V., J. E. Lasley and P. T. Mayer. 1956. Genetic and environmental factors affecting litter size in swine. Mo. Agr. Exp. Sta. Res. Bull. 615.

Revelle, T. J. and O. W. Robison. 1973. An explanation for the low heritability of litter size in swine. J. Anim. Sci. 37:668.

Rio, P. R. 1957. Genetic interpretation of heterosis and maternal effects in reproduction and growth of swine. Unpublished Ph.D. Thesis. University of Illinois, Urbana.

Robertson, G. L., L. E. Casida, R. H. Grummer and A. B. Chapman. 1951. Some feeding and management factors affecting age at puberty and related phenomena in Chester White and Poland China gilts. J. Anim. Sci. 10:841.

Squiers, C. D., G. E. Dickerson and D. T. Mayer. 1952. Influence of inbreeding, age and growth rate of sows on sexual maturity, rate of ovulation, fertilization and embryo survival. Mo. Agr. Exp. Sta. Res. Bull. 494.

Stewart, H. A. 1945. An appraisal of factors affecting prolificacy in swine. J. Anim. Sci. 4:250.

Warnick, A. C., E. L. Wiggens, L. E. Casida, R. H. Grummer and A. G. Chapman. 1951. Variation in puberty phenomena in inbred gilts. J. Anim. Sci. 10:479.

Young, L. D. and I. T. Omtvedt. 1973. Influence of the litter in which a gilt is raised and her own performance on her subsequent reproductive performance. Okla. Agr. Exp. Sta. Res. Rep. 